\title{
Effect of partial replacement of cement with slag on the early-age strength of concrete
}

1 Kangkang Tang PhD, CEng, MICE

Senior Lecturer, University of Wolverhampton, Wolverhampton, UK (corresponding author: kangkangtang@gmail.com)

2 Jamal Khatib BEng, MSc, PhD, CEng, EUR ING, FICE, FHEA Professor, Department of Civil and Environmental Engineering, Beirut Arab University, Beirut, Lebanon
3 Greg Beattie PhD, CEng, MICE Associate Director, Arup, Liverpool, UK
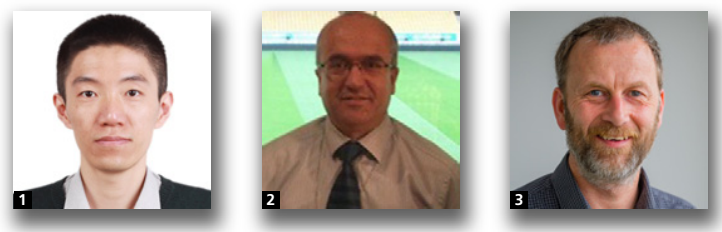

Concrete structures are popularly used to provide open space areas that are often incorporated into the design of sports, social and industrial structures. One of the concerns with concrete structures, especially long-span concrete structures, is early-age thermal expansion and subsequent contraction as a result of the exothermic cement hydration reaction. Thermal contraction, externally restrained by vertical structural elements such as columns and shear walls, may cause thermal cracking if it exceeds the tensile strength of the concrete. The early-age thermal loading of cast-in-place concrete can be estimated through isothermal calorimetry, semi-adiabatic calorimetry and finite-element modelling (FEM). This paper discusses the efficiency of using FEM, based on the isothermal calorimetry results, for predicting early-age temperature development of in situ concrete. In addition, this work quantifies the beneficial effect of using ground granulated blast-furnace slag as a partial replacement of cement in structural concrete. The simulation results, validated via semi-adiabatic calorimetry, indicate reduced thermal loading due to the presence of slag. This can be taken as an advantage of using such slag in structural concrete.

\section{Notation}

A

$h$

$k$

$P$

$Q$

$Q_{t}$

$Q_{t+20 \mathrm{~s}}$

$q_{x}, q_{y}, q_{z}$

$T$

$T_{1}$

$T_{\mathrm{f}}$

$T_{\mathrm{s}}$

$t$

$\partial T / \partial x, \partial T / \partial y, \partial T / \partial z$ heat transfer surface area $\left(\mathrm{m}^{2}\right)$ convection factor $\left(\mathrm{W} / \mathrm{m}^{2}{ }^{\circ} \mathrm{C}\right)$ thermal conductivity $\left(\mathrm{W} / \mathrm{m}^{\circ} \mathrm{C}\right)$ heat output rate $(\mathrm{W} / \mathrm{g})$ cumulative heat $(\mathrm{J})$ accumulated heat $(\mathrm{J})$ at time $t$ accumulated heat $(\mathrm{J})$ at time $t+20 \mathrm{~s}$ heat transfer rate $(\mathrm{W})$ in a three-dimensional Cartesian coordinate system temperature $\left({ }^{\circ} \mathrm{C}\right)$ short-term temperature difference factor $\left({ }^{\circ} \mathrm{C}\right)$ ambient temperature inside environmental chamber $\left({ }^{\circ} \mathrm{C}\right)$ concrete surface temperature $\left({ }^{\circ} \mathrm{C}\right)$ time (s)

temperature gradients $\left({ }^{\circ} \mathrm{C} / \mathrm{m}\right)$ in a three-dimensional Cartesian coordinate system

\section{Introduction}

Large open spaces are commonly required by sports, social and industrial projects, creating a demand for structures with high space efficiency. However, this may pose some major design challenges when using structural concrete due to earlyage thermal contraction caused by the cement hydration reaction. Significant resultant internal stresses (or thermal stresses) will build up if these movements are externally restrained by vertical structural elements (e.g. columns). Contractions in a suspended concrete slab against external restraints will lead to tensile stresses, which may cause deleterious tensile cracking of the concrete. Bamforth (2007) and Zheng et al. (2005) defined thermal loading by introducing a short-term temperature difference factor $T_{1}\left({ }^{\circ} \mathrm{C}\right)$, which is the difference between the peak temperature during the cement hydration reaction and the ambient temperature at the time of casting. Higher thermal loading ( $T_{1}$ values) was obtained at a curing temperature of $35^{\circ} \mathrm{C}$ than at a standard curing temperature of $20^{\circ} \mathrm{C}$. This indicates an accelerated hydration reaction of cement under hot curing conditions. A high ambient temperature in conjunction with insufficient curing may also have a detrimental effect on the strength of concrete (ACI, 1999). It is therefore important to quantify the heat development in cast-in-place concrete to allow for crack control and damage mitigation.

Adiabatic calorimetry, semi-adiabatic calorimetry and isothermal calorimetry tests are commonly used to determine the thermal loading ( $T_{1}$ values) for concrete. An adiabatic 
calorimeter measures the temperature rise within a mortar or concrete specimen, given perfect thermal insulation that can contain all the heat generated from cement hydration inside the system. The temperature rises obtained from an adiabatic calorimeter can be taken as a conservative estimation of the real values at the core of a mass concrete pour. An isothermal calorimeter can directly measure the heat output rate of cement, given a constant temperature, noting that the rate of the hydration reaction is affected by the curing temperature. However, Xu et al. (2010) reported that predicted early-age concrete hydration temperatures based on isothermal calorimetry test results were lower than those measured on site. The heat output rate of cement obtained in an isothermal condition may therefore be an underestimate of the real values at the core of a concrete element such as a flat slab. In summary, both adiabatic calorimetry and isothermal calorimetry tests may give biased results due to the different curing conditions of cast-in-place concrete.

In contrast to an adiabatic calorimeter, the insulation used in a semi-adiabatic calorimeter is not perfect and a fraction of the heat generated during cement hydration can escape from the system. The semi-adiabatic calorimeter also allows temperature variations in a concrete or mortar specimen during measurement and this may be taken as a way of simulating what happens during real-life construction projects (i.e. nonisothermal and non-adiabatic). Wadsö (2002) developed a method to use isothermal calorimetry results to simulate the hydration reaction process in concrete under varying temperature conditions. Isothermal calorimetry tests were conducted at different curing temperatures $\left(20,30,40\right.$ and $\left.50^{\circ} \mathrm{C}\right)$. A tenthorder polynomial regression analysis was conducted to determine the correlation between the heat output rates and the cumulative heat outputs at different curing temperatures. A second-order polynomial regression was then conducted to estimate the real-life heat output rate based on the isothermal calorimetry test results obtained at different curing temperatures. This method shows a possibility of using the isothermal calorimeter, a well-defined piece of experimental apparatus, to predict concrete heat development by considering real-life ambient temperature variations. Wadsö (2002) used mortar specimens for both the isothermal calorimetry and semiadiabatic calorimetry tests. As concrete specimens also contain coarse aggregate, the applicability of this simulation process to a concrete specimen requires justification, and this is presented in this paper.

A review of the literature revealed that the volumes of specimens used for semi-adiabatic calorimetry tests vary significantly, as summarised in Table 1. Tang et al. (2015a) investigated the effects of specimen size on concrete heat development. Concrete slab specimens of size $350 \times 250 \times 300 \mathrm{~mm}$ were initially cast inside an insulated plywood box to simulate $300 \mathrm{~mm}$ thick flat slab curing conditions. Four sides of the specimen were insulated with $20 \mathrm{~mm}$ thick expanded polystyrene sheets. To investigate the effect of concrete specimen size on heat development, larger concrete slab specimens of size $660 \times 460 \times 300 \mathrm{~mm}$ were cast inside $100 \mathrm{~mm}$ thick timber boards, inside which $20 \mathrm{~mm}$ thick expanded polystyrene sheets were used as insulation materials. The experimental results, validated by finite-element modelling (FEM) simulations, indicated that the curing conditions of a suspended concrete slab were better modelled with a larger concrete specimen (i.e. $660 \times 460 \times 300 \mathrm{~mm}$ ) in conjunction with sufficient insulation materials.

The heat development of ground granulated blast-furnace slag (GGBS) concrete mixes during early ages is slower than that of mixes with only CEM I only. This can be attributed to the two-stage hydration process of GGBS - GGBS first reacts with the alkalis in the cement and then with the calcium hydroxide released by the hydrated cement (Regourd, 1983). The low early-age strength development in GGBS concrete can also be attributed to this two-stage effect. A higher curing temperature will increase the amount of alkalis released from the cement hydration, which can facilitate the reactions of GGBS, in conjunction with higher early-age strengths (Robins et al., 2006). The peak hydration temperature of cement containing GGBS as a partial replacement of CEM I cement is lower than that of CEM I only mixes. As a result, the peak temperature in fresh GGBS concrete is lower and this will result in reduced thermal contraction and thermal loading. There is scope to use GGBS in structural concrete such as suspended flat slabs for crack mitigation purposes. However, the partial replacement of cement with GGBS has a retardation effect on the early-age strength of concrete. This may lead to premature failure of concrete in tension caused by early-age thermal contraction. To justify the use of GGBS in structural concrete,

Table 1. Use of semi-adiabatic calorimeters in the literature

$\begin{array}{lll}\text { Reference } & \text { Specimen size } & \text { Insulation material and thickness } \\ \text { Da Silva et al. (2013) } & 0.24 \mathrm{~m} \times 0.24 \mathrm{~m} \times 0.24 \mathrm{~m} & 100 \mathrm{~mm} \text { expanded polystyrene } \\ \text { Kim et al. (2011) } & 0.30 \mathrm{~m} \times 0.30 \mathrm{~m} \times 0.30 \mathrm{~m} & 100 \mathrm{~mm} \text { expanded polystyrene } \\ \text { Azenha et al. (2009) } & 0.6 \mathrm{~m} \times 0.3 \mathrm{~m} \times 0.6 \mathrm{~m} & 21 \mathrm{~mm} \text { plywood }+60 \mathrm{~mm} \text { expanded polystyrene } \\ \text { Lawrence et al. (2012) } & 1.0 \mathrm{~m} \times 1.0 \mathrm{~m} \times 1.0 \mathrm{~m} & 19 \mathrm{~mm} \text { plywood }+75 \mathrm{~mm} \text { expanded polystyrene } \\ \text { Tang et al. (2015a) } & 0.35 \times 0.25 \times 0.30 \mathrm{~mm} & 17 \mathrm{~mm} \text { plywood }+20 \mathrm{~mm} \text { expanded polystyrene } \\ \text { Tang et al. (2015b) } & 0.66 \times 0.46 \times 0.30 \mathrm{~mm} & 100 \mathrm{~mm} \text { timber }+20 \mathrm{~mm} \text { expanded polystyrene }\end{array}$


it is important to verify if this retardation effect can be mitigated by the beneficial effect of reduced thermal loading. Wang et al. (2012) reported that the strength contribution of GGBS was greatly enhanced under a high curing temperature $\left(65^{\circ} \mathrm{C}\right)$. This was attributed to the denser microstructure caused by the development of calcium silicate hydrate gels in GGBS-blended concrete specimens. It should also be noted that there is a high risk of delayed ettringite formation in concrete if the hydration temperature is in excess of $70^{\circ} \mathrm{C}$, and this may lead to expansion in cement paste and cracking in concrete (Bamforth, 2007).

\section{Experimental procedures and results}

This study aimed to contribute to a better understanding of the early-age heat development of cast-in-place concrete elements such as flat slabs. The heat development process was simulated in the laboratory using semi-adiabatic calorimetry. A FEM simulation was performed based on the heat output rates measured from isothermally cured mortar specimens and validated by the semi-adiabatic calorimetry tests on concrete specimens. The FEM simulation results were then used to estimate the thermal loading (or $T_{1}$ values) in concrete slabs made with CEM I only and GGBS-blended concretes.

\subsection{Materials, concrete mix proportions and strength test}

The cement used for this project was CEM I 42.5 and the GGBS used satisfied the requirements for GGBS according to BS EN 15167-1 (BSI, 2006a), with a specific surface area of $425 \mathrm{~m}^{2} / \mathrm{kg}$. The coarse aggregate used was $5-40 \mathrm{~mm}$ graded crushed gravel with a water absorption value of $0.88 \%$. The fine aggregate was well-graded medium sand with a water absorption value of $2 \cdot 62 \%$. Five concrete mixes (Table 2), with up to $70 \%$ CEM I replaced with GGBS, were produced in the laboratory to investigate the effect of the partial replacement of CEM I with GGBS on the early-age strength and heat development of concrete. The target strength of the $0 \%$ GGBS mix was to achieve $\mathrm{C} 30 / 37$ concrete with a suitable workability for floor slab casting (BSI, 2006b). The free water/binder (w/b) ratio for each mix was adjusted to ensure that the desired workability requirement (i.e. a slump range above $100 \mathrm{~mm}$ ) was achieved. Standard concrete cube specimens $(150 \times 150 \times$ $150 \mathrm{~mm}$ ) were cast alongside the slab specimens. The cube specimens were demoulded within $24 \mathrm{~h}$ after casting and cured in two water curing tanks respectively set at $20^{\circ} \mathrm{C}$ and $38^{\circ} \mathrm{C}$. $38^{\circ} \mathrm{C}$ represents typical hot climatic conditions in Shanghai, China (CMA, 2004). Concrete compressive strength tests were conducted after $3 \mathrm{~d}$ and $28 \mathrm{~d}$ and the results are shown in Figure 1.

\subsection{Semi-adiabatic calorimetry and isothermal calorimetry tests}

The continuous curing conditions of a concrete flat slab were simulated in the laboratory using a semi-adiabatic calorimeter. A concrete slab specimen $(660 \times 460 \times 300 \mathrm{~mm})$ was cast inside an insulated box constructed from $100 \mathrm{~mm}$ thick timber boards (Figure 2(a)). Four sides of the specimen were insulated with $20 \mathrm{~mm}$ thick expanded polystyrene sheets to simulate $300 \mathrm{~mm}$ thick flat slab curing conditions. The underside of the specimen was in contact with a $50 \mathrm{~mm}$ timber board and the top surface was exposed to air. This allowed heat losses to occur from both the top and base of the concrete, which is similar to on-site concrete slab conditions. The concrete specimens, inside the insulated timber board box, were placed in an environmental chamber (Figure 2(b)) after casting. Thermocouples were embedded into the specimens to record the temperature every $10 \mathrm{~min}$ for $3 \mathrm{~d}$. The results are shown in Figure 3. Semi-adiabatic calorimetry tests were conducted inside the environmental chamber at a constant temperature of $38^{\circ} \mathrm{C}$. The actual temperatures inside the environmental chamber were also monitored and, while some variations were observed, the curing temperatures were found to be generally within $\pm 5^{\circ} \mathrm{C}$ of the specified temperature (Figure 4).

A TAM Air isothermal calorimeter was used to measure the heat output rate during the hydration reaction of cementitious materials at a constant temperature. Approximately $10 \mathrm{~g}$ of CEM I only and GGBS-blended cement samples were tested with the same w/b ratio as the concrete mixes presented in Table 2. This allowed the results obtained from mortar samples to be comparable to the heat generated in the equivalent concrete mixes. The mixes tested were

$0 \% \mathrm{GGBS}$ at $20^{\circ} \mathrm{C}$
$0 \% \mathrm{GGBS}$ at $38^{\circ} \mathrm{C}$
$50 \% \mathrm{GGBS}$ at $20^{\circ} \mathrm{C}$
$50 \% \mathrm{GGBS}$ at $38^{\circ} \mathrm{C}$
$70 \% \mathrm{GGBS}$ at $20^{\circ} \mathrm{C}$
$70 \% \mathrm{GGBS}$ at $38^{\circ} \mathrm{C}$

\begin{tabular}{lcccc} 
& Total binder content: $\mathbf{k g} / \mathbf{m}^{\mathbf{3}}$ & Free $\mathbf{w} / \mathbf{b}$ ratio & Sand: $\mathbf{k g} / \mathbf{m}^{\mathbf{3}}$ & $\mathbf{5 - 4 0} \mathbf{~ m m ~} \mathbf{~ g r a v e l : ~} \mathbf{~ k g} / \mathbf{m}^{\mathbf{3}}$ \\
\hline 0\% GGBS concrete & 398 & 0.49 & 690 & 1092 \\
15\% GGBS concrete & 398 & 0.51 & 690 & 1092 \\
30\% GGBS concrete & 398 & 0.50 & 690 & 1092 \\
50\% GGBS concrete & 398 & 0.51 & 690 & 1092 \\
70\% GGBS concrete & 398 & 0.51 & 690 & 1092
\end{tabular}




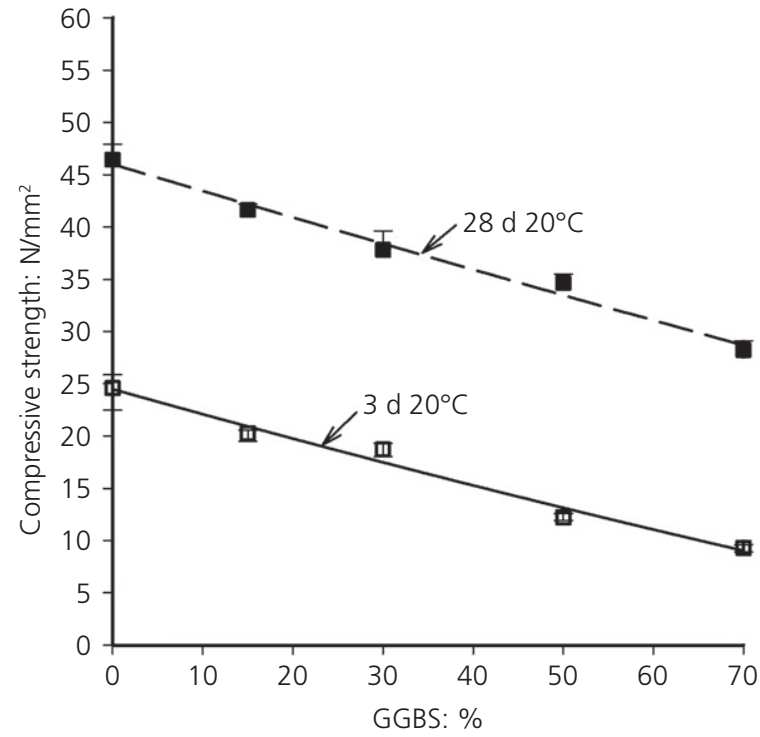

(a)

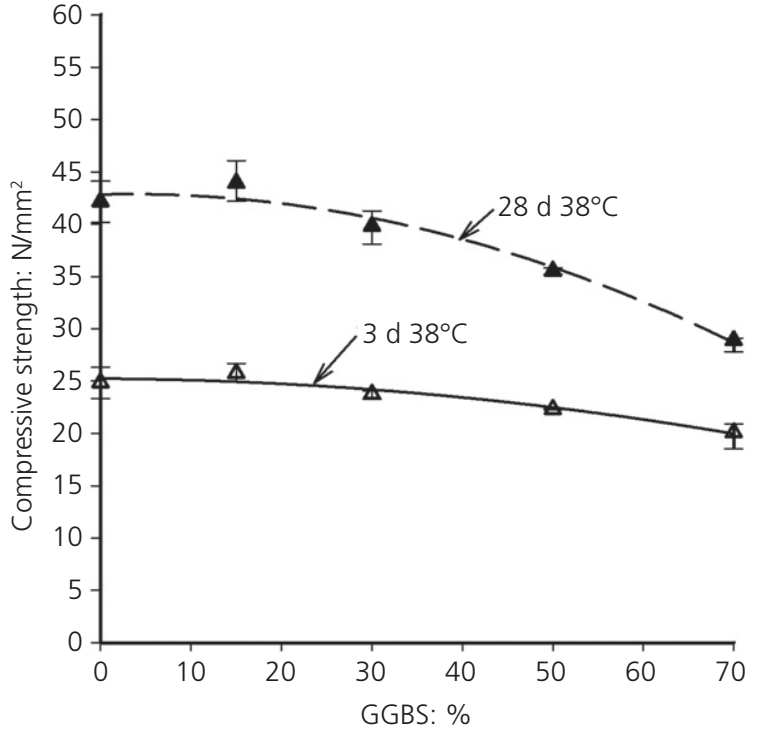

(b)

Figure 1. Compressive strengths at $3 \mathrm{~d}$ and $28 \mathrm{~d}$ : (a) $20^{\circ} \mathrm{C}$ curing (b) $38^{\circ} \mathrm{C}$ curing

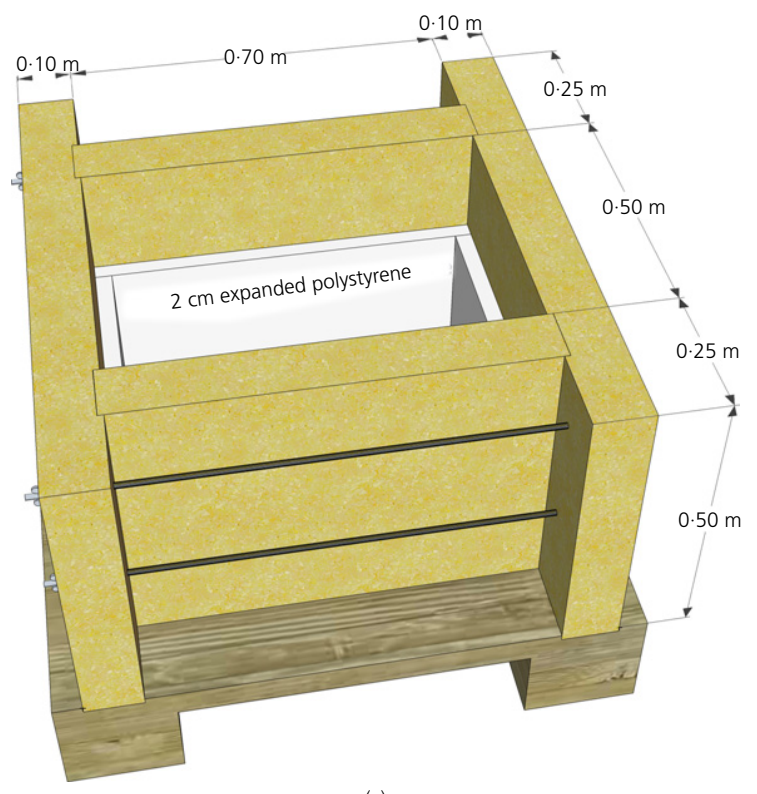

(a)

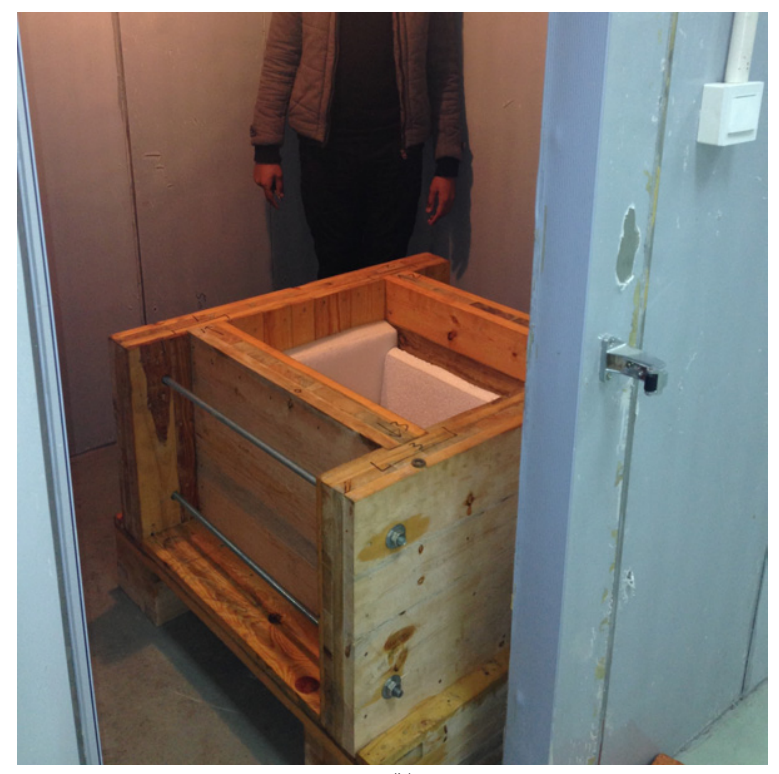

(b)

Figure 2. Semi-adiabatic calorimeter: (a) timber mould; (b) environmental chamber

The TAM Air isothermal calorimeter recorded the heat output rate in Watts, which was then converted into a heat output rate per gram of binder $(\mathrm{W} / \mathrm{g})$. The interval between successive measurements was $20 \mathrm{~s}$. Figure 5 shows the heat output rates measured from the mixes listed above. The cumulative heat release was calculated by integrating the heat release rate (Figure 5); the results are shown in Figure 6.

\section{FEM procedures}

Numerical simulations of concrete heat development were conducted using the multi-physics finite-element software package Ansys. The temperature rise during concrete construction is primarily due to the exothermic hydration reaction of the cementitious materials (i.e. CEM I and GGBS in this study). In the FEM, this was achieved by introducing the 


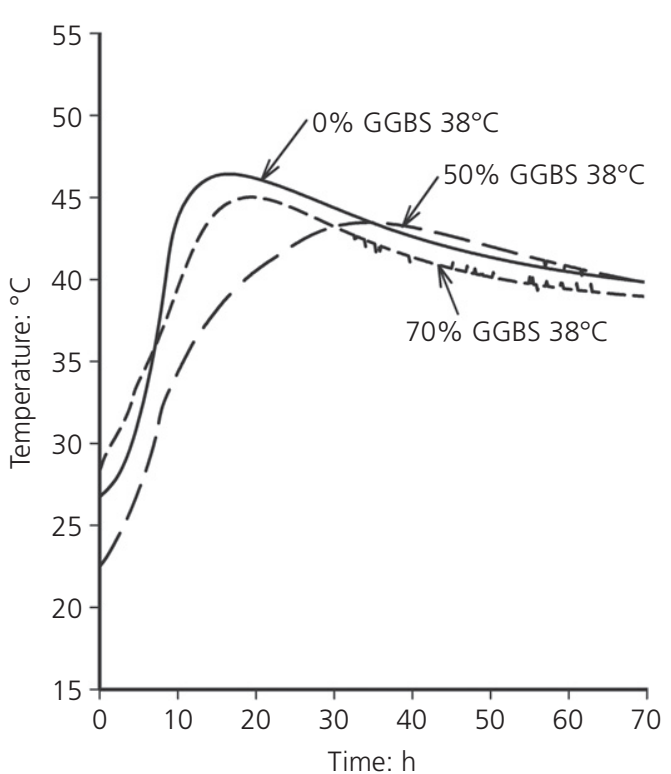

Figure 3. Concrete slab semi-adiabatic calorimetry test results

heat output rates of concrete $\left(\mathrm{W} / \mathrm{m}^{3}\right)$ which were converted from the heat output rates obtained from the isothermally cured mortar samples $(\mathrm{W} / \mathrm{g})$ based on the mix proportions shown in Table 2 .

Figure 7 shows the correlation between heat output rates $(P)$ and the calculated cumulative heat values $(Q)$. An attempt to address the effects of curing temperature variations on the heat output rates was conducted using the method proposed by Wadsö (2002) as discussed in Section 1. This method is based on the assumption that the degree of cement hydration is directly proportional to the cumulative heat output during the hydration heat liberation process. A tenth-order polynomial regression analysis was conducted and the analysis results are also shown in Figure 7. This process was facilitated through Matlab programming. The deduced regression analysis curves match the experimental results very well. However, the accuracy of the tenth-order polynomial regression was reduced significantly for GGBS-blended cement samples at an elevated curing temperature of $38^{\circ} \mathrm{C}$ (Figure 7(b)). The irregularities (i.e. peaks and troughs) observed in the measurements were smoothed out. The tenth-order polynomial regression did not simulate the second peak of the hydration reaction very well either. The second peak in GGBS concrete mixes might be due to their separate hydrations at different time intervals.

A linear regression analysis was then conducted to estimate an adjusted heat output rate based on the heat output rates at $20^{\circ} \mathrm{C}$ and $38^{\circ} \mathrm{C}$ respectively at each time step. The accumulated heat $\left(Q_{t}\right)$ was then calculated to determine the heat output rate at the next time step $\left(Q_{t+20 \mathrm{~s}}\right)$ according to Equation 1 . A $20 \mathrm{~s}$ time step, which is identical to the isothermal calorimeter measurement rate, was used.

1. $Q_{t+20 \mathrm{~s}}=\int_{t}^{t+20 s} P \mathrm{~d} t+Q_{t}$

A flow of heat between concrete and the surrounding insulation materials (i.e. expanded polystyrene and timber board) was achieved in the FEM using the law of heat

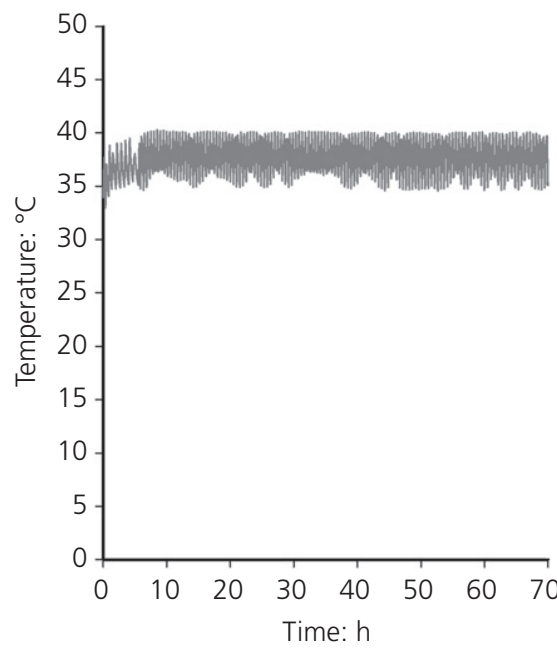

(a)

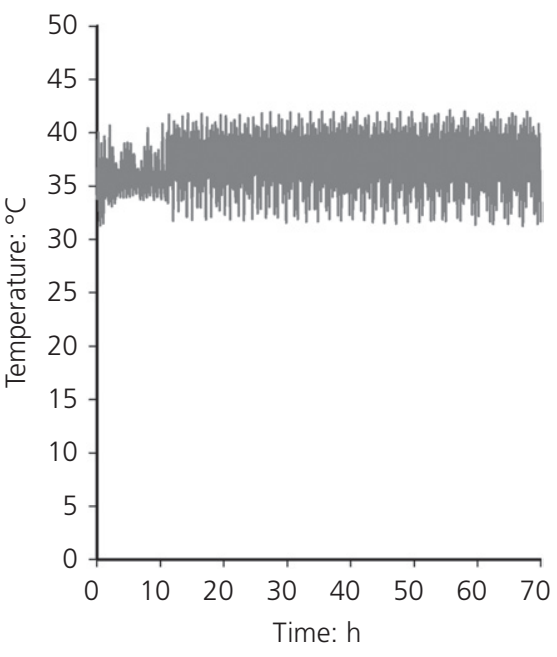

(b)

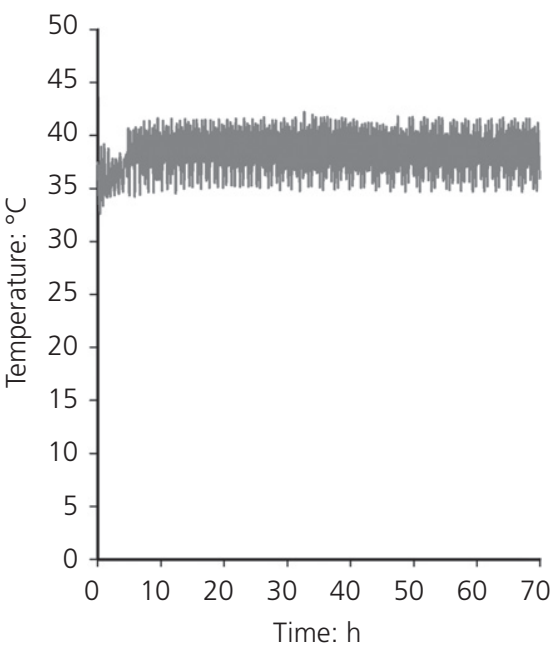

(c)

Figure 4. Environmental chamber temperatures: (a) $0 \%$ GGBS cured at $38^{\circ} \mathrm{C}$; (b) $50 \%$ GGBS cured at $38^{\circ} \mathrm{C}$; (c) $70 \%$ GGBS cured at $38^{\circ} \mathrm{C}$ 


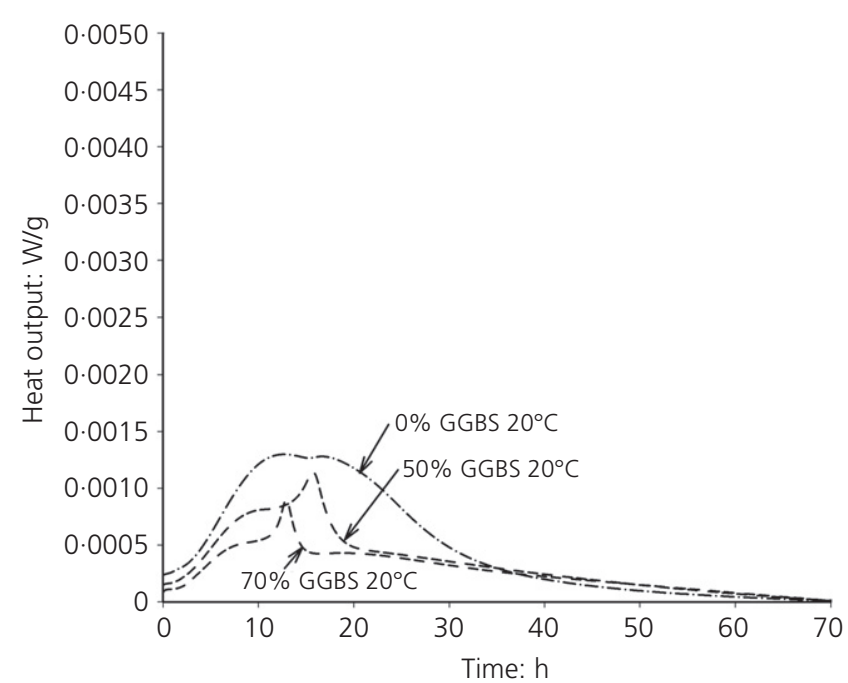

(a)

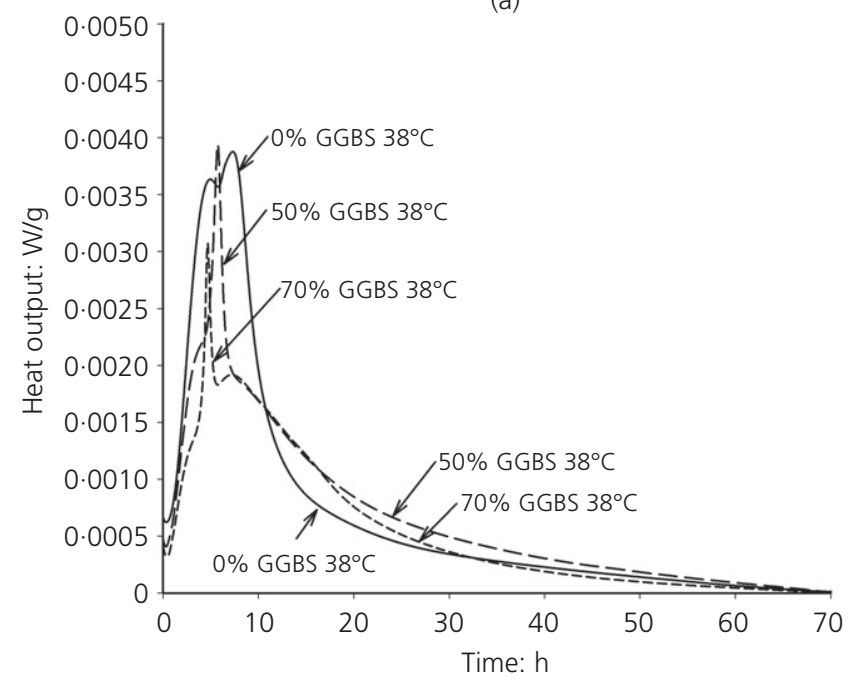

(b)

Figure 5. Isothermal calorimetry test results obtained from mortar specimens: (a) $20^{\circ} \mathrm{C}$ curing; (b) $38^{\circ} \mathrm{C}$ curing

conduction (Moaveni, 1999)

2. $q_{x}=-k A \frac{\partial T}{\partial x}$

3. $q_{y}=-k A \frac{\partial T}{\partial y}$ where $q_{x}, q_{y}$ and $q_{z}$ are heat transfer rates (W) in a threedimensional Cartesian coordinate system, $\partial T / \partial x, \partial T / \partial y$ and $\partial T / \partial z$ are temperature gradients $\left({ }^{\circ} \mathrm{C} / \mathrm{m}\right)$ in a three-dimensional Cartesian coordinate system, $A$ is the heat transfer surface area $\left(\mathrm{m}^{2}\right)$ and $k$ is the thermal conductivity $\left(\mathrm{W} / \mathrm{m}^{\circ} \mathrm{C}\right)$.

The thermal conductivities of concrete, expanded polystyrene and timber board used in the FEM were 1.7, 0.0624 and $0 \cdot 15 \mathrm{~W} / \mathrm{m}^{\circ} \mathrm{C}$, respectively, which were obtained from the literature (Lawrence et al., 2012). The effect of reinforcement on the thermal conductivity of reinforced concrete was not taken into account in this work. To define the heat loss from the upper surface of the concrete, a constant convection factor of $5.6 \mathrm{~W} / \mathrm{m}^{2 \circ} \mathrm{C}$, obtained from the literature (Lawrence et al., 2012), was used in the FEM. The ambient temperature $\left(T_{\mathrm{f}}\right)$ was set to be identical to the temperature measured inside the environmental chamber (Figure 4). The convective heat transfer in the FEM is governed by Newton's law of cooling

5. $q=h A\left(T_{\mathrm{s}}-T_{\mathrm{f}}\right)$

where $T_{\mathrm{s}}$ is the concrete surface temperature $\left({ }^{\circ} \mathrm{C}\right), T_{\mathrm{f}}$ is the ambient temperature inside the environmental chamber $\left({ }^{\circ} \mathrm{C}\right)$ and $h$ is a convection factor $\left(\mathrm{W} / \mathrm{m}^{2 \circ} \mathrm{C}\right)$

Both the concrete and insulation materials were meshed into $10 \times 10 \times 10 \mathrm{~mm}$ eight-node hexahedron solid elements, as shown in Figure 8. Only one fourth of the semi-adiabatic test (Figure 2), which included 69125 elements in total, was modelled utilising the symmetry of the whole model about two vertical planes.

\section{Results and discussion}

Partial replacement of CEM I with GGBS had a retardation effect on both the 3-d and 28-d strengths of concrete at the standard curing temperature of $20^{\circ} \mathrm{C}$. Figure 1(a) indicates that with $70 \%$ of CEM I replaced with GGBS, the 3-d compressive strength reduced from $24.6 \mathrm{~N} / \mathrm{mm}^{2}$ to $9 \cdot 3 \mathrm{~N} / \mathrm{mm}^{2}$. This retardation effect was also identified at the age of $28 \mathrm{~d}$. The average 28-d compressive strength of the 70\% GGBS mix was $28.2 \mathrm{~N} / \mathrm{mm}^{2}$, which was significantly lower than that of $0 \%$ GGBS mix, $46.4 \mathrm{~N} / \mathrm{mm}^{2}$. This retardation effect may therefore prevent the application of GGBS in structural concrete in winter when the ambient temperature is well below $20^{\circ} \mathrm{C}$. However, the retardation effect of GGBS on the earlyage strength of concrete was mitigated by its beneficial effects under hot environmental conditions $\left(38^{\circ} \mathrm{C}\right)$, especially at early ages. With $70 \%$ of CEM I replaced with GGBS, the 3-d compressive strength only reduced from 24.9 to $20 \cdot 1 \mathrm{~N} / \mathrm{mm}^{2}$ (Figure 1(b)).

As mentioned earlier, the isothermal calorimeter recorded the heat output rate in Watts. Figure 5 shows that the presence of GGBS contributed to a modest reduction in the peak heat 


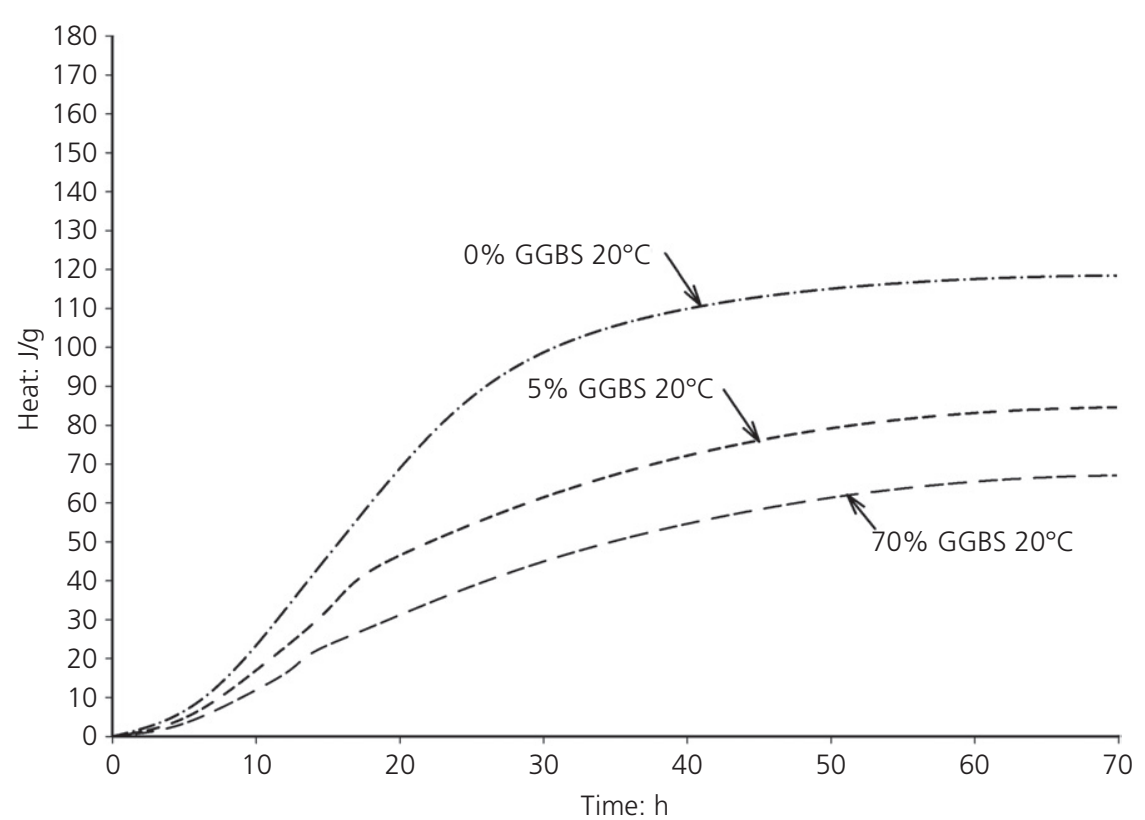

(a)

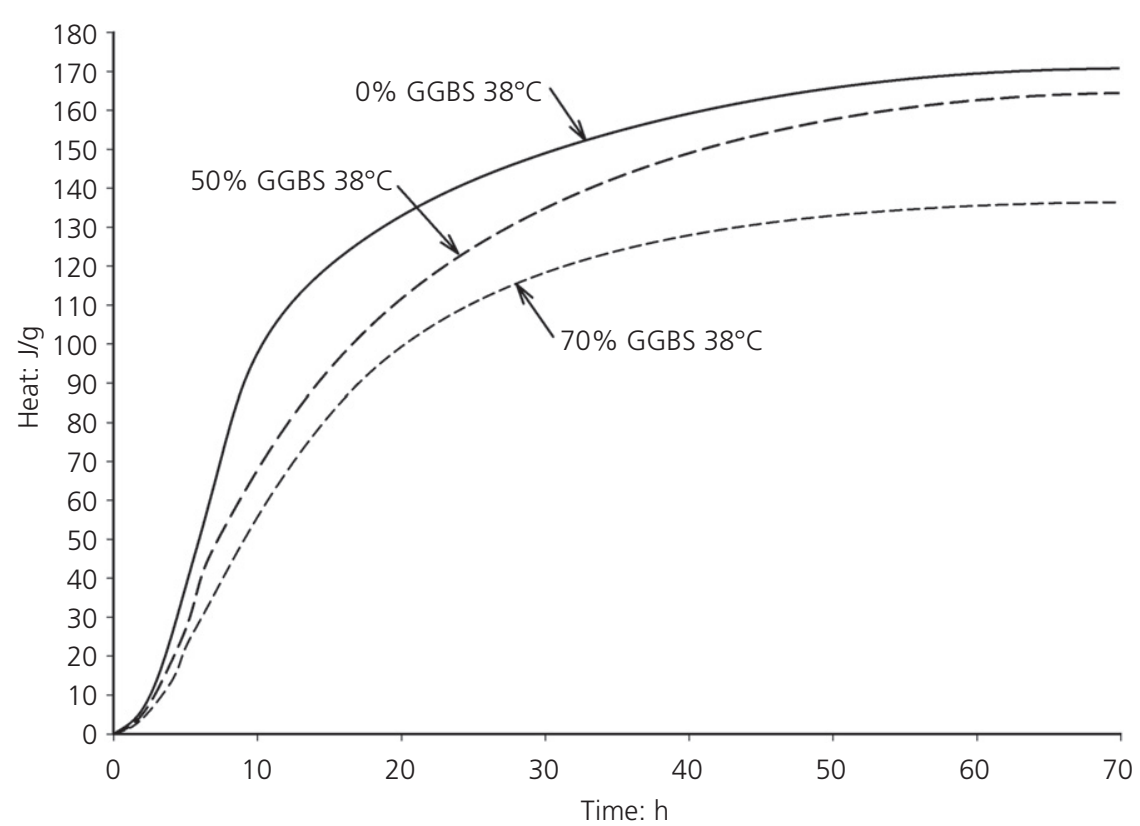

(b)

Figure 6. Cumulative heat $(\mathrm{J} / \mathrm{g})$ versus time obtained from mortar specimens: (a) $20^{\circ} \mathrm{C}$ curing; (b) $38^{\circ} \mathrm{C}$ curing

output rate. It also took less time to reach the peak heat output rate at an elevated temperature of $38^{\circ} \mathrm{C}$ for both the CEM I only and the GGBS-blended samples. This finding agrees with the work of Ballim and Graham (2009) and indicates that a higher curing temperature accelerated the hydration reaction of both the CEM I and the GGBS mixes. This could also be attributed to another process; that is, the retardation effect of gypsum inside CEM I will be diluted due to the presence of GGBS (Ballim and Graham, 2009).
Figure 6 indicates the cumulative heat release $(\mathrm{J} / \mathrm{g})$ calculated by integrating the heat release rate (Figure 5). At a standard curing temperature of $20^{\circ} \mathrm{C}$, the $3-\mathrm{d}$ cumulative heat of the $0 \%$ GGBS mix was 39\% higher than that of the $50 \%$ GGBS mix. The heat mitigation effect of GGBS dropped significantly at an elevated curing temperature of $38^{\circ} \mathrm{C}$. The 3 -d cumulative heat of the $50 \%$ GGBS mix was $165 \mathrm{~J} / \mathrm{g}$, which was only marginally lower that of the $0 \%$ GGBS mix (i.e. $171 \mathrm{~J} / \mathrm{g}$ ). This indicates that, with up to $50 \%$ of cement replaced with GGBS, 


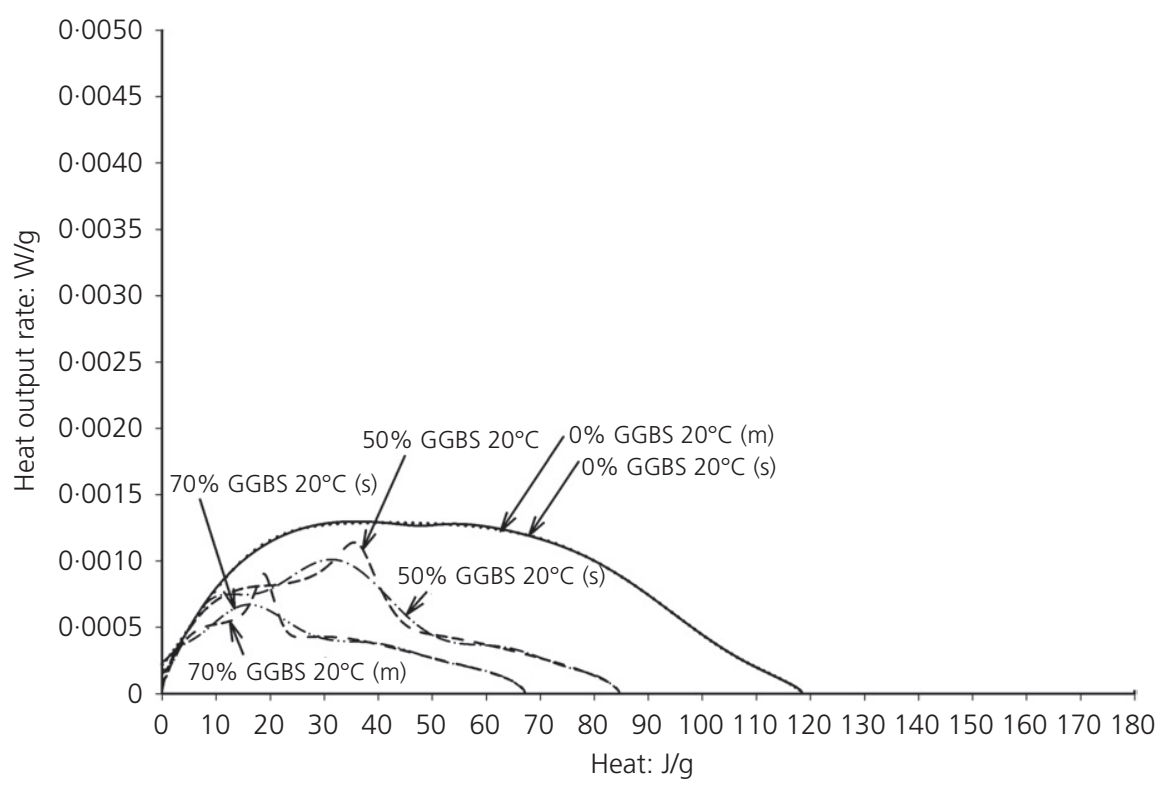

(a)

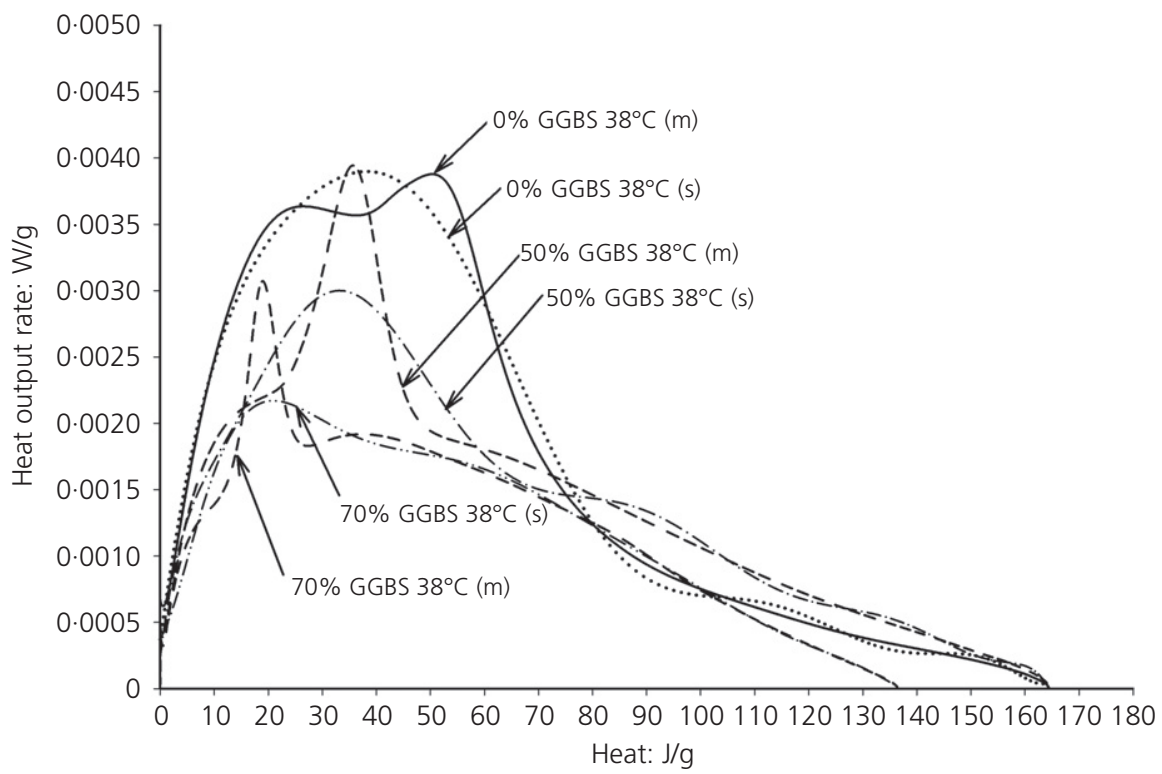

(b)

Figure 7. Heat output rate $(\mathrm{W} / \mathrm{g})$ versus cumulative heat $(\mathrm{J} / \mathrm{g})$ obtained from mortar specimens for (a) $20^{\circ} \mathrm{C}$ curing and (b) $38^{\circ} \mathrm{C}$ curing; $(\mathrm{s})$ represents simulated results and $(\mathrm{m})$ represents measured results

the heat mitigation effect is going to be very limited at elevated curing conditions, such as are present at the core of a mass concrete pour. At a high replacement ratio ( $70 \%$ in this study), the 3-d cumulative heat was $136 \mathrm{~J} / \mathrm{g}$, which was $20 \%$ lower than that of the $0 \%$ GGBS mix.

Peak heat outputs obtained from the isothermal calorimetry are shown in Table 3. The presence of GGBS reduced the time taken to reach the peak heat output rate. This could be attributed to the retardation effect of gypsum in the CEM I, which was diluted due to the presence of GGBS. For concrete specimens cured semi-adiabatically, the time to reach the peak hydration temperature was significantly extended, as shown in Table 4. This could be attributed to the reduced heat dissipation effect of a large and well-insulated concrete slab specimen, which helped to maintain the concrete core temperature. Approximately $33 \mathrm{~h}$ were required for the $50 \%$ GGBS concrete mix to reach the peak value and this was much longer than that of the $\%$ GGBS and $70 \%$ GGBS mixes $(16 \cdot 2$ and $19 \mathrm{~h}$ respectively). This could be due to variations in the initial 


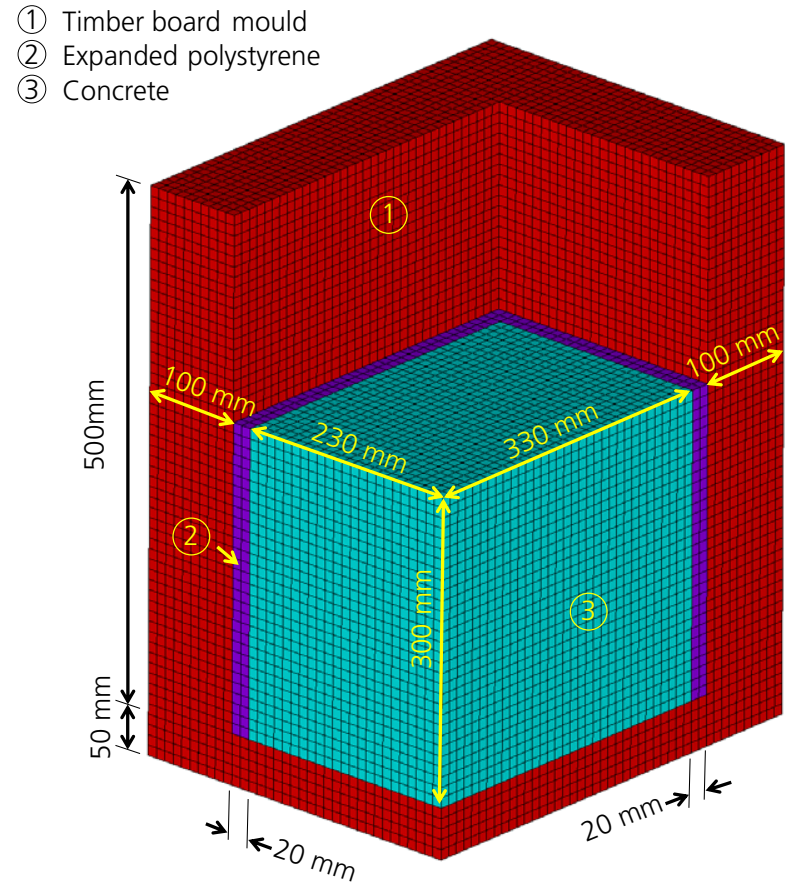

Figure 8. Finite element model (a quarter model)

Table 3. Mortar peak heat output rate (isothermal calorimetry test) at $38^{\circ} \mathrm{C}$

\begin{tabular}{|lcc|}
\hline & $\begin{array}{c}\text { Peak hydration heat } \\
\text { output rate: } \mathbf{W} / \mathbf{g}\end{array}$ & $\begin{array}{c}\text { Time to reach } \\
\text { peak: } \mathbf{h}\end{array}$ \\
\hline 0\% GGBS concrete & $3.88 \times 10^{-3}$ & 7.3 \\
$50 \%$ GGBS concrete & $3.94 \times 10^{-3}$ & 5.7 \\
$70 \%$ GGBS concrete & $3.07 \times 10^{-3}$ & 4.7 \\
\hline
\end{tabular}

Table 4. Mortar peak hydration temperature (semi-adiabatic calorimetry test) at $38^{\circ} \mathrm{C}$

\begin{tabular}{|lcc|}
\hline & $\begin{array}{c}\text { Peak hydration } \\
\text { temperature: }{ }^{\circ} \mathbf{C}\end{array}$ & $\begin{array}{c}\text { Time to reach } \\
\text { peak: } \mathbf{h}\end{array}$ \\
\hline 0\% GGBS concrete & $46 \cdot 4$ & $16 \cdot 2$ \\
\hline $50 \%$ GGBS concrete & $43 \cdot 5$ & $33 \cdot 2$ \\
$70 \%$ GGBS concrete & $45 \cdot 0$ & $19 \cdot 0$ \\
\hline
\end{tabular}

casting temperatures. Between 20 and $40 \mathrm{~h}$ after casting, the heat output rate of the $50 \%$ GGBS mix was higher than that of both the $\%$ GGBS and 70\% GGBS mixes (Figure 5(b)), and this could also contribute to a later higher measured temperature.

Finite-element modelling is an effective tool for predicting concrete hydration temperature development. Figure 9 shows the temperature-time curves for the slab model, as shown in
Figure 2, under semi-adiabatic conditions. FEM simulation results of the concrete core temperature development, labelled FEM in Figure 9, were based on the heat output rates directly determined according to the results obtained from isothermally cured mortar specimens (Figure 5). The FEM simulation based on the adjusted heat output rates are labelled in Figure 9 as FEM Plus. The FEM simulations gave very accurate predictions of both the temperature history curves and the peak hydration temperatures of the specimens. The predicted peak temperatures were almost identical to the experimental results and this justifies the assumption that the heat output rates obtained from mortar samples can be directly used to simulate the heat development of concrete specimens. This can also be attributed to the specimen size along with sufficient insulation materials $(100 \mathrm{~mm}$ timber board and $20 \mathrm{~mm}$ expanded polystyrene), which effectively prevent heat ingress from the lateral boundaries. In addition, the accuracy of the FEM was not affected by variations in the curing temperatures. The FEM simulations based on the adjusted heat output rates (FEM Plus curves) do not improve the accuracy of the results any further. This indicates that the hydration output rates obtained under isothermal conditions can be used to predict the peak hydration temperatures if the variations in curing temperature are within $\pm 5^{\circ} \mathrm{C}$ of the prescribed values (i.e. $38^{\circ} \mathrm{C}$ for this project). There is a potential to improve the accuracy of the FEM simulation results by using cement hydration output rates obtained under temperature-matched curing conditions, which are more closely related with the temperature history measured on site. This is an area of ongoing research of this project.

The FEM simulation results, validated by the semi-adiabatic calorimetry tests, show a modest reduction in thermal loading (or $T_{1}$ values) from 8.4 to $7^{\circ} \mathrm{C}$ with $70 \% \mathrm{CEM}$ I replaced with GGBS. $T_{1}$ values are defined as the difference between the peak hydration temperatures and the ambient temperature at the time of casting. This modest reduction in $T_{1}$ values can be attributed to the higher curing temperature $\left(38^{\circ} \mathrm{C}\right)$, which accelerated the hydration heat liberation process of both CEM I and GGBS mixes. This finding also agrees with the isothermal calorimetry test results (Figure 6). Thermal loading ( $T_{1}$ values) can be used to define the early-age thermal actions in a thermal analysis. The magnitude of the concrete tensile stresses can then be evaluated to calculate the minimum amount of supplementary crack control reinforcement to prevent the yield of the existing slab reinforcement, as discussed elsewhere (Tang et al., 2015b).

\section{Conclusions}

Partial replacement of cement with GGBS has a retardation effect on the early-age strength of concrete. However, this retardation effect becomes less significant at an elevated curing temperature $\left(38^{\circ} \mathrm{C}\right.$ in this study), which indicates the beneficial effect of using GGBS in concrete in hot climatic conditions. Isothermal calorimetry and semi-adiabatic calorimetry tests were conducted to investigate the heat development of concrete 


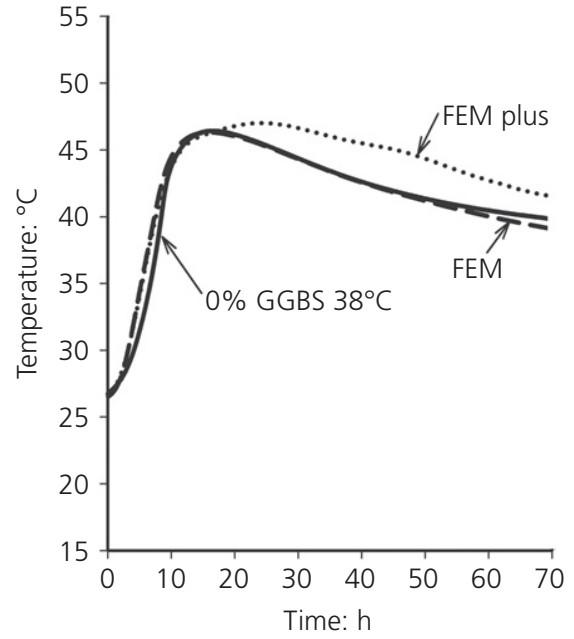

(a)

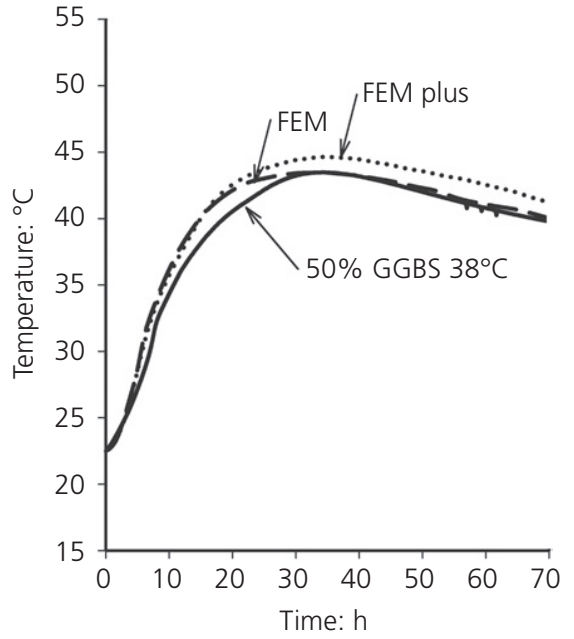

(b)

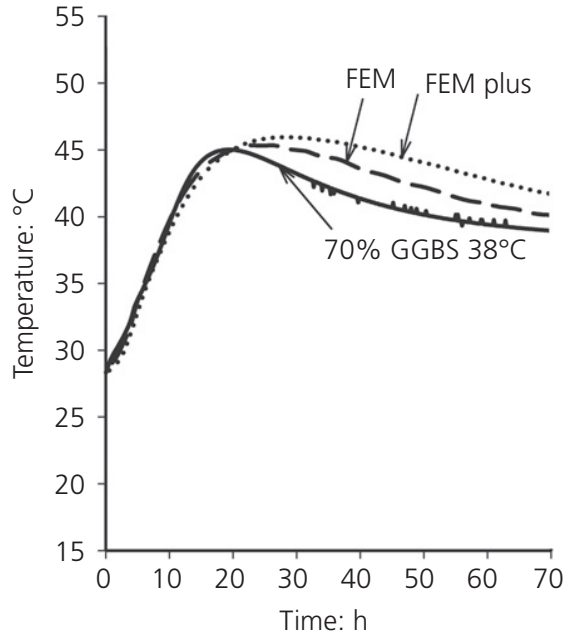

(c)

Figure 9. Concrete slab semi-adiabatic test and FEM simulation results: (a) $0 \%$ GGBS cured at $38^{\circ} \mathrm{C}$; (b) $50 \%$ GGBS cured at $38^{\circ} \mathrm{C}$; (c) $70 \%$ GGBS cured at $38^{\circ} \mathrm{C}$

when CEM I was partially replaced with GGBS. The FEM simulation results indicate that isothermal calorimetry results can be effectively used to simulate concrete heat development under variable temperature conditions such as those commonly encountered during concrete casting. This should encourage the use of GGBS in cast-in-place concrete due to the savings made from reductions in crack-control reinforcement as a result of the reduced thermal effect. The FEM simulation results, validated by the semi-adiabatic calorimetry tests, also showed a beneficial effect of using GGBS in concrete structures during warm seasons. With $70 \%$ of CEM I replaced with GGBS, thermal loading (or $T_{1}$ values) reduced by $17 \%$. This can be taken as an advantage of the use of GGBS in structural concrete.

\section{REFERENCES}

ACl (American Concrete Institute) (1999) ACI 305R: Hot weather concreting. ACI, Farmington Hills, MI, USA.

Azenha M, Faria R and Ferreira D (2009) Identification of early-age concrete temperatures and strains: monitoring and numerical simulation. Cement \& Concrete Composites 31(6): 369-378.

Ballim Y and Graham PC (2009) The effects of supplementary cementing materials in modifying the heat of hydration of concrete. Materials and Structures 42(6): 803-811.

Bamforth PB (2007) Early-age Thermal Crack Control in Concrete. Ciria, London, UK, Ciria C660.

BSI (2006a) BS EN 15167-1:2006: Ground granulated blast furnace slag for use in concrete, mortar and grout. Part 1 - definitions, specifications and conformity criteria. BSI, London, UK

BSI (2006b) BS 8500-1: 2006: Complementary British Standard to BS EN 206-1. Method of specifying and guidance for the specifier. BSI, London, UK.
CMA (China Meteorological Administration) (2004) Chinese Ground Temperature Monthly Data (1961 to 1990). CMA, Beijing, China. See http://www.cma.gov.cn/ (accessed 15/12/2014).

Da Silva WRL, Smilauer V and Stemberk P (2013) Upscaling semi-adiabatic measurements for simulating temperature evolution of mass concrete structures. Materials and Structures 48(4): 1031-1041.

Kim GY, Lee EB, Nam JS and Koo KM (2011) Analysis of hydration heat and autogenous shrinkage of high-strength mass concrete. Magazine of Concrete Research 63(5): 377-389, http://dx.doi.org/ 10.1680/macr.9.00106.

Lawrence AM, Tia M, Ferraro CC and Bergin M (2012) Effect of early age strength on cracking in mass concrete containing different supplementary cementitious materials: experimental and finite-element investigation. Journal of Materials in Civil Engineering 24(4): 362-372.

Moaveni S (1999) Finite Element Analysis - Theory and Application with ANSYS. Prentice-Hall, Upper Saddle River, NJ, USA.

Regourd M (1983) Microanalytical studies (X-ray photo electron spectrometry) of surface hydration reactions of cement compounds. Technology in the 1990s: developments in hydraulic cements. Proceedings of a Royal Society Discussion Meeting. Royal Society, London, UK, pp. 85-92.

Robins PJ, Austin SA and Issaad A (2006) Suitability of GGBFS as a cement replacement for concrete in hot arid climates. Materials and Structures 25(10): 598-612.

Tang K, Millard S and Beattie G (2015a) Early-age heat development in GGBS concrete structures. Proceedings of the Institution of Civil Engineers - Structures and Buildings 168(8): 541-553, http:/ dx.doi.org/10.1680/stbu.14.00089.

Tang K, Millard S and Beattie G (2015b) Technical and economical feasibility of using GGBS in long-span concrete structures. Advances in Concrete Construction 3(1): 1-14.

Wadsö L (2002) An Experimental Comparison between Isothermal Calorimetry, Semi-Adiabatic Calorimetry and Solution Calorimetry for the Study of Cement Hydration. Lund University, Lund, Sweden, Final Report Nordtest project 1534-01.

Wang Q, Miao M, Feng J and Yan P (2012) The influence of high temperature curing on the hydration characteristics of a 
cement-GGBS binder. Advances in Cement Research 24(1):

33-40, http://dx.doi.org/10.1680/adcr.2012.24.1.33.

Xu Q, Ruiz JM, Hu J, Wang K and Rasmussen RO (2010) Modeling hydration properties and temperature developments of early-age concrete pavement using calorimetry tests. Thermochimica Acta 512(1-2): 76-85.
Zheng L, Paine KA and Dhir RK (2005) Early-age temperature rises in GGBS concrete: part 1: determination of $T_{1}$ values. In International Congress - Global Construction: Ultimate Concrete Opportunities (Dhir RK, Harrison TA and Newlands MD (eds)). Thomas Telford, London, UK, pp. $173-182$.

\section{How can you contribute?}

To discuss this paper, please email up to 500 words to the editor at journals@ice.org.uk. Your contribution will be forwarded to the author(s) for a reply and, if considered appropriate by the editorial board, it will be published as discussion in a future issue of the journal.

Proceedings journals rely entirely on contributions from the civil engineering profession (and allied disciplines). Information about how to submit your paper online is available at www.icevirtuallibrary.com/page/authors, where you will also find detailed author guidelines. 